\title{
RESIDENTIAL LOCATION, WORKPLACE LOCATION, AND BLACK EARNINGS
}

\author{
Edwin A. Sexton*
}

\begin{abstract}
Despite the fairly large amount of research devoted to the topic, the debate continues over the relationship between residential location, workplace location, and black economic well-being as measured by employment and/or earnings.

The current work compares the eamings of black workers who live and work in the central city to otherwise equal blacks who live and work in the suburbs. In addition, we decompose the black/white intrametropolitan earnings differential into three parts: 1 . that portion caused by differences in the characteristics of blacks and whites, 2 . that portion due to differences in the market valuation of these characteristics, and 3. that portion due to differences in the spatial characteristics of blacks and whites.

We find both that residential/workplace combinations significantly impact earnings and that, of the portion of the earnings gap explained by differences in characteristics, a significant part is explained by differences in spatial characteristics.
\end{abstract}

\section{INTRODUCTION}

Throughout the last two decades housing market discrimination and labor force discrimination were fairly popular (and fairly separate) topics of study. Only a relatively few social scientists have chosen to study the interaction between these two types of discrimination. Specifically, the question has become: what impact, if any, does housing market discrimination, and hence segregation, have on the labor force opportunities and outcomes of the discriminated against group(s).

John Kain (1968), in one of the earliest pieces in this area, hypothesized that the post World War II suburbanization of employment had adversely impacted on black economic well-being by limiting the size and distribution of black employment. Most recent studies, including the current one, have focused on black earnings, with some researchers finding depressed eamings among black central city residents who work in the central city relative to their suburban counterparts of equal ability [Vrooman and Greenfield, (1980); Price and Mills, (1985)]. Other studies have observed no such earnings disadvantage [Danziger and Weinstein (1976); Straszheim, (1980)].

\footnotetext{
*Assistant Professor, Department of Economics, The Wichita State University. The author acknowledges the grant support of the W. Frank Barton School of Business at The Wichita State University, the helpful comments of two anonymous referees, and the research assistance of Janet F. Nickel. He alone assumes responsibility for the contents.
} 
The importance of this debate can perhaps best be described in terms of the policy prescription which would be applied according to the results which are found. If it is true that central city blacks who work in the central city have lower earnings than suburban blacks who work in the suburbs then our policies might be best directed toward dispersing blacks, who typically have been heavily segregated within the central cities, more evenly throughout the metropolitan area. Generally, those policies which are mentioned which would affect this end are increased low-income housing in the suburbs, efforts to reduce discrimination in already existing suburban housing markets, and/or increased transportation from the central cities to the suburbs [Reid, (1985)].

If, on the other hand, blacks in the suburbs are not doing any better than those in the central city, policy efforts might more effectively be focused on upgrading and renewing the urban center. Of course, even if this later result is found, dispersal of the black population might still be a worthy policy goal, independent of the lack of effects on earnings. Proponents of the former view have long felt that massive efforts to renew the urban center are morally indefensible since these efforts are, in effect, encouraging blacks to remain in a residentialworkplace combination which is detrimental to their economic and social wellbeing.

A central assumption of Kain's thesis and many of those that followed is that blacks are segregated in the central city, far away from employment opportunities. Further, the assumption is that immobility in the housing markets (perhaps because of discrimination in the suburban market or perhaps because of the lack of low-income housing there) prevents migration. Additionally, poor transportation and information networks from the central city to the suburbs lower the amount of commuting that would otherwise take place. The implicit, if not stated, assumption in each of these studies is that if those trapped in the central city could just migrate or commute to the suburbs, they would be better off, at least in terms of earnings and/or employment.

The empirical test of this assumption involves comparing the earnings of black workers who live and work in the central city to otherwise equal blacks who live and work in the suburbs. If blacks who live and work in the suburbs earn more than their central city counterparts this would lend credibility to the Kain assertion that ghetto dispersal is a superior policy goal to urban renewal. 
Ultimately, we would like to determine why an earnings differential persists between white and black workers. We shall attempt to decompose the white/black intrametropolitan earnings differential into its component parts. By decomposing the earnings differential it is hoped that we will be able to detect which of the various influences on black earnings is most responsible for their generally poor earnings outcomes. This should provide further insight into this continuing debate and suggest possible avenues for future research.

The empirical test mentioned above, along with a description of the data and sample, will be detailed in section II of this paper. The results will be outlined in section III and a concluding section will summarize the findings and discuss the resulting policy implications.

\section{DATA, SAMPLE, AND METHODOLOGY}

The B Sample of the 1980 Public-use data is employed for two primary reasons. First, its individual data makes it ideal for the study of eamings among groups. In addition, it contains data on both the place of residence of each worker and the place of work.

We choose to look at the wage and salary earnings of black and white males, ages 16 to 65 in the 15 largest SMSAs in the United States. These SMSAs are: New York, Nassau-Suffolk, Los Angeles, San Francisco, Anaheim-Santa Ana, St. Louis, Detroit, Dallas, Houston, Baltimore, D.C., Philadelphia, Pittsburgh, Chicago, and Atlanta. Self-employed individuals are excluded from the sample and, given the need to be able to identify residential and workplace locations by central city and suburbs, this leaves us with a sample of 45,412 white males and 6,697 black males.

We proceed by using OLS to estimate eamings equations for both groups with the natural $\log$ of annual earnings as the dependent variable and a variety of standard independent variables such as level of schooling, experience, occupational category, marital status, and others. We focus on the inclusion of three residential-workplace dummies. ${ }^{1}$ Controlling for workers who live and work in the suburbs (SBSB) in the intercept of the equations we include dummies for those who live and work in the central city (CCCC), those who live in the central cities and work in the suburbs (CCSB), and those who live in the suburbs and work in the central cities (SBCC). 
The inclusion of these dummy variables will allow us to test the hypothesis outlined in the introduction that workers who are segregated into the central cities of large SMSAs are at an earnings disadvantage compared to their suburban counterparts. While we would expect the coefficient on CCCC to be negative for both blacks and whites, to the extent that blacks are more constrained in their housing options than are whites we might expect the coefficient on CCCC to be larger in absolute value for blacks than it is for whites.

Since we have pooled data from 15 SMSAs in our sample we control for regional variations by including three regional dummies, the northcentral region being included in the intercept. In addition, we control for price level variation across SMSAs by including the log of the housing price index (LHPI) and for SMSA specific market conditions by including the average unemployment rate in each SMSA (SMSAUR).

The mean values of the black and white samples and the results of the race specific regressions are discussed next.

\section{EMPIRICAL RESULTS}

\section{Sample Mean Characteristics}

The mean characteristics of the white and black samples are summarized in Table 1. Several differences which would tend to contribute to a white-black earnings gap stand out. First, white males have slightly over one year more education than do black males on average. In addition, the average white worker in our sample works approximately two hours more per week and just over one week more per year than the average black worker. Lastly, the average white worker is more likely than the average black worker to be married and to work in the most advantageous occupational categories. Each of these characteristic differences contributes to the earnings differential between whites and blacks.

Our focus in this paper is the spatial differences between whites and blacks and these differences are quite pronounced in Table 1 . While only $24 \%$ of whites live and work in the central cities of these SMSAs, nearly 57\% of blacks do. Additionally, nearly $20 \%$ of whites commute from the suburbs to the central cities for work while only $10.5 \%$ of blacks are in this residential-workplace combination. Further, fully $50 \%$ of whites live and work in the suburbs while only $20 \%$ of blacks do. 
TABLE 1

Definition Of Variables And Their Race Specific Means

\begin{tabular}{|c|c|c|}
\hline Variable & $\begin{array}{l}\text { White Male } \\
\text { Mean }\end{array}$ & $\begin{array}{l}\text { Black Male } \\
\text { Mean }\end{array}$ \\
\hline EDUC: Years of schooling completed & 14.4483 & 13.4052 \\
\hline EXPER: Age - EDUC - 5 & 18.0043 & 18.4515 \\
\hline EXPER $^{2}$ : EXPER squared & 508.7707 & 511.9298 \\
\hline HOURS: Hours worked per week in 1979 & 41.3934 & 39.4425 \\
\hline WEEKS: Number of weeks worked in 1979 & 47.8930 & 46.5790 \\
\hline $\begin{array}{l}\text { MARRIED: } 1 \text { if married (not separated) } \\
0 \text { otherwise. }\end{array}$ & 0.6600 & 0.5752 \\
\hline $\begin{array}{l}\text { OTHMAR: } 1 \text { if separated,divorced,widowed } \\
0 \text { otherwise. }\end{array}$ & 0.0780 & 0.1561 \\
\hline $\begin{array}{l}\text { SINGLE: } 1 \text { if never married } \\
0 \text { otherwise. }\end{array}$ & 0.2620 & 0.2687 \\
\hline $\begin{array}{l}\text { KIDS: } 1 \text { if children are in the household } \\
0 \text { if otherwise. }\end{array}$ & 0.4583 & 0.4890 \\
\hline $\begin{array}{l}\text { LHPI: Natural log of the housing price } \\
\text { index for the SMSA in } 1979 .\end{array}$ & 2.4169 & 2.4144 \\
\hline SMSAUR: Unemployment rate in the SMSA in 1979. & 6.7741 & 6.7587 \\
\hline $\begin{array}{l}\text { WEST: } 1 \text { if SMSA is in the west } \\
0 \text { otherwise. }\end{array}$ & 0.2007 & 0.1485 \\
\hline $\begin{array}{l}\text { SOUTH: } 1 \text { if SMSA is in the south } \\
0 \text { otherwise. }\end{array}$ & 0.1567 & 0.1679 \\
\hline $\begin{array}{l}\text { NEAST: } 1 \text { if SMSA is in the northeast } \\
0 \text { otherwise. }\end{array}$ & 0.3853 & 0.4455 \\
\hline $\begin{array}{l}\text { NCENTR: } 1 \text { if SMSA is in the northcentral states. } \\
0 \text { otherwise }\end{array}$ & 0.2573 & 0.2381 \\
\hline $\begin{array}{l}\text { MANAGER: } 1 \text { if employed in as a manager } \\
0 \text { otherwise. }\end{array}$ & 0.1771 & 0.0901 \\
\hline $\begin{array}{l}\text { PROFESS: } 1 \text { if a professional } \\
0 \text { otherwise. }\end{array}$ & 0.1322 & 0.0682 \\
\hline $\begin{array}{l}\text { SALE,TECH, } \\
\text { CLER: } 1 \text { if employed in sales,technical, } \\
\text { or clerical occupation } \\
0 \text { otherwise. }\end{array}$ & 0.2248 & 0.2127 \\
\hline $\begin{array}{l}\text { CRAFT: } 1 \text { if employed in craft or repair occupation } \\
0 \text { otherwise. }\end{array}$ & 0.2779 & 0.4920 \\
\hline $\begin{array}{l}\text { SERVICE: } 1 \text { if employed in service } \\
\text { or labor occupation } \\
0 \text { otherwise. }\end{array}$ & 0.1880 & 0.1370 \\
\hline $\begin{array}{l}\text { CCCC: } 1 \text { if central city resident who } \\
\text { works in the central city. } \\
0 \text { otherwise. }\end{array}$ & 0.2436 & 0.5692 \\
\hline $\begin{array}{l}\text { CCSB: } 1 \text { if central city resident who } \\
\text { works in the suburbs. } \\
0 \text { otherwise. }\end{array}$ & 0.0538 & 0.1281 \\
\hline $\begin{array}{l}\text { SBCC: } 1 \text { if suburban resident who } \\
\text { works in the central city. } \\
0 \text { otherwise. }\end{array}$ & 0.1987 & 0.1048 \\
\hline $\begin{array}{l}\text { SBSB: } 1 \text { if suburban resident who } \\
\text { works in the suburbs. } \\
0 \text { otherwise. }\end{array}$ & 0.5039 & 0.1979 \\
\hline
\end{tabular}


As a worker's characteristics, spatial or otherwise, only partially explain his earmings, we turn now to our regression results which will reveal the market valuation of the characteristics discussed above.

\section{Regression Results}

The results of our OLS regressions are summarized in Table 2. With the dependent variable being the natural log of eamings the coefficients on the independent variables can be interpreted as the percentage change in earnings resulting from a one unit change in the exogenous variable, holding all else equal. For instance, we observe that white males can expect approximately $5.7 \%$ more in earnings for each additional year of schooling while the educational return for black males is about $5.0 \%$, ceteris paribus. Due to our focus on the spatial component of our earnings equations we are particularly concerned with the coefficients on the three included residential-workplace dummies. Two important findings are of note.

First, while both white and black workers experience an earnings penalty for central city residence and workplace as compared to their otherwise equal suburban counterparts, the penalty for blacks is twice that for whites. White males who live and work in the central city earn nearly $4 \%$ less than equally qualified whites who live and work in the suburbs. For black male central city resident workers the earnings deficit when compared to their suburban counterparts is just over eight percent. As noted in the previous section, blacks are over twice as likely than whites to have this particular residential-workplace combination, thus contributing to their overall earnings gap.

The other significant spatial finding was that the premium enjoyed by whites and blacks who live in the suburbs and work in the central city over otherwise equal whites and blacks who live and work in the suburbs is approximately the same. Whites who live in the suburbs and commute to work in the central city earn $9.41 \%$ more than equal whites who live and work in the suburbs. Blacks who live in the suburbs and work in the central city earn $9.38 \%$ more than black suburban resident workers. Though this coefficient is practically identical for whites and blacks, we again note that whites are twice as likely as blacks to be in this favorable residential-workplace combination. 
TABLE 2

Race Specific Earnings Coefficients

Dependent Variable - Ln (Eamings)

\begin{tabular}{|c|c|c|}
\hline Variables & White Males & Black Males \\
\hline INTERCEPT & $\begin{array}{l}2.9006 \\
(6.510)\end{array}$ & $\begin{array}{l}0.1456 \\
(0.120)\end{array}$ \\
\hline EDUCATION & $\begin{array}{c}0.0568 \\
(45.386)\end{array}$ & $\begin{array}{c}0.0501 \\
(13.015)\end{array}$ \\
\hline EXPER & $\begin{array}{c}0.0511 \\
(54.343)\end{array}$ & $\begin{array}{r}0.0421 \\
(15.625)\end{array}$ \\
\hline EXPER2 & $\begin{array}{c}-0.0009 \\
(-41.667)\end{array}$ & $\begin{array}{c}-0.0006 \\
(-11.501)\end{array}$ \\
\hline HOURS & $\begin{array}{c}0.0151 \\
(48.409)\end{array}$ & $\begin{array}{c}0.0124 \\
(14.301)\end{array}$ \\
\hline WEEKS & $\begin{array}{c}0.0384 \\
(111.066)\end{array}$ & $\begin{array}{c}0.0385 \\
(45.396)\end{array}$ \\
\hline PROFESSIONALS & $\begin{array}{l}-0.0379 \\
(-3.437)\end{array}$ & $\begin{array}{l}0.0893 \\
(1.997)\end{array}$ \\
\hline SALES,TECH,CLER & $\begin{array}{c}-0.1250 \\
(-12.996)\end{array}$ & $\begin{array}{l}-0.0509 \\
(-1.444)\end{array}$ \\
\hline CRAFT, REPAIR & $\begin{array}{c}-0.2084 \\
(-20.701)\end{array}$ & $\begin{array}{l}-0.1035 \\
(-3.082)\end{array}$ \\
\hline SERVICE, LABOR & $\begin{array}{l}-0.0415 \\
(-3.972)\end{array}$ & $\begin{array}{l}0.0264 \\
(0.685)\end{array}$ \\
\hline OTHMAR & $\begin{array}{l}-0.1074 \\
(-9.213)\end{array}$ & $\begin{array}{l}-0.1221 \\
(-4.629)\end{array}$ \\
\hline SINGLE & $\begin{array}{c}-0.2713 \\
(-29.050)\end{array}$ & $\begin{array}{l}-0.2408 \\
(-8.873)\end{array}$ \\
\hline KIDS & $\begin{array}{l}-0.0283 \\
(-4.135)\end{array}$ & $\begin{array}{l}-0.0553 \\
(-2.778)\end{array}$ \\
\hline LHPI & $\begin{array}{l}1.2744 \\
(6.853)\end{array}$ & $\begin{array}{l}2.4286 \\
(4.816)\end{array}$ \\
\hline SMSAUR & $\begin{array}{l}0.0057 \\
(3.039)\end{array}$ & $\begin{array}{l}0.0127 \\
(2.447)\end{array}$ \\
\hline WEST & $\begin{array}{l}-0.0661 \\
(-5.502)\end{array}$ & $\begin{array}{l}-0.1027 \\
(-2.921)\end{array}$ \\
\hline SOUTH & $\begin{array}{l}-0.1122 \\
(-7.369)\end{array}$ & $\begin{array}{l}-0.1431 \\
(-3.472)\end{array}$ \\
\hline NEAST & $\begin{array}{l}-0.0649 \\
(-6.895)\end{array}$ & $\begin{array}{l}-0.0582 \\
(-2.098)\end{array}$ \\
\hline $\mathrm{CCCC}$ & $\begin{array}{l}-0.0381 \\
(-5.047)\end{array}$ & $\begin{array}{l}-0.0816 \\
(-3.499)\end{array}$ \\
\hline CCSB & $\begin{array}{l}-0.0043 \\
(-0.324)\end{array}$ & $\begin{array}{l}0.0063 \\
(0.198)\end{array}$ \\
\hline SBCC & $\begin{array}{c}0.0941 \\
(11.755)\end{array}$ & $\begin{array}{l}0.0938 \\
(2.788)\end{array}$ \\
\hline$F_{2}$ & $2,891.1$ & 273.57 \\
\hline$R^{2}$ & .56 & .45 \\
\hline $\mathbf{N}$ & 45,412 & 6,697 \\
\hline
\end{tabular}


Since we do observe an earnings differential between white and black males in these SMSAs we will follow the methodology used by Blinder (1973) and attempt to apportion this differential initially into two parts: (1.) that portion due to whites and blacks having different characteristics and (2.) that portion due to whites and blacks having their characteristics valued differently by the market.

Algebraically this decomposition can be expressed as:

$$
\ln E^{W}-\ln E^{B}=\left(X^{W}-X^{B}\right) \beta^{W^{\prime}}+\left(\beta^{W}-\beta^{B}\right) X^{B^{\prime}}
$$

where $E$ is earnings, $X$ is a vector of average worker characteristics influencing $E$, $\beta$ is the estimated coefficient vector, and the superscripts $W$ and $B$ denote white and black workers respectively. The first argument on the right hand side of equation (1) corresponds to the first component of the earnings gap described above and the second term on the right hand side of equation (1) corresponds to the second component of the earnings gap.

Using the estimated coefficients reported in Table 2 and the mean values from Table 1 we see that, overall, white men in our sample earn approximately $39 \%$ more than the black men. About 23 of those percentage points (or 59\% of the gap) represent the portion of the earnings differential which is explained by white and black men differing in their characteristics. The remaining 16 percentage points (or $41 \%$ of the gap) represent the portion which is due to the fact that the market values white and black characteristics differently, or to factors for which we have not controlled.

Since the focus of this paper is the impact of spatial factors on black and white earnings we might well pose two important questions: (1.) By how much would the average black male's eamings rise if he retained all of his characteristics except that he had the locational characteristics of the average white male?; and (2.) By how much would the average black male's earnings rise if he retained all of his characteristics and received the "return" on his own locational characteristics that the average white male receives?

Table 3 presents the findings which answer these two questions. First, the average black male's earning would rise by about $3.6 \%$ if he were to retain all of his mean characteristics except that he were dispersed throughout the metropolitan area in the same residential-workplace pattern as the average white male. Second, if this average black male worker were to retain all of his characteristics, including spatial ones, but were given the coefficients on the white intrametropolitan locational variables, his earnings would increase by $2.4 \%$. 
TABLE 3

Black Male Earnings Estimated At White Locational Means and With White Locational Returns ${ }^{\mathrm{a}}$

Black Male Earnings

9.225768

Black Male Earnings

at White Locational Means ${ }^{\mathrm{b}}$

9.260672

Black Male Earnings with White Locational Returns ${ }^{\mathrm{b}}$

9.249175

Reported in Ln Earnings
Including only the intrametropolitan binary variables CCCC, CCSB, SBCC

\section{CONCLUSION}

Our findings appear to indicate that blacks are twice as likely as whites to find themselves in the least advantageous residential-workplace combination in the metropolitan area. Moreover, the penalty they suffer for being in this spatial combination is over twice that suffered by whites in the same situation.

While urban renewal might be a worthy goal, it is also possible that such policies which increase the attractiveness of remaining in the central city without increasing job opportunities there might well be encouraging blacks and others to remain in a residential-workplace combination which is detrimental to their economic well-being. The evidence suggests that some combination of dispersing blacks more evenly throughout the metropolitan area, and increasing the returns that blacks receive on their locational characteristics will aid in closing the whiteblack intrametropolitan earnings gap.

Despite the spatial contribution to this gap, however, it remains evident that a significant portion of the average difference in white and black male earnings is due to differences in nonlocational variables such as educational attainment, hours worked per week, and weeks worked per year. The fact that locational variables account for even one-fifth of this gap, however, suggests that policy makers determined to narrow this gap must reckon with these spatial considerations. 


\section{ENDNOTES}

1. Four residential/race specific equations were also estimated with similar results. When white and black equations were estimated for central city residents, central city workplace was a detriment for both blacks and whites; the penalty for blacks being slightly more than double that for whites. Among suburban residents, a city workplace was a boon to both whites and blacks, the advantage to whites being only slightly larger than that for blacks.

\section{REFERENCES}

Blinder, Alan S. "Wage Discrimination: Reduced Form and Structural Estimates." The Journal of Human Resources B.4 (1973): 436-455.

Danziger, Sheldon, and Michael Weinstein. "Employment Location and Wage Rates of Poverty-Area Residents." Journal of Urban Economics 3 (1976): 127-145

Kain, John. F. "Housing Segregation, Negro Employment, and Metropolitan Decentralization." Quarterly Journal of Economics 82.2 (1968): 175-197.

Price, Richard and Edwin Mills. "Race and Residence in Earnings Determination." Journal of Urban Economics 17 (1985): 1-18.

Reid, Clifford E. "The Effect of Residential Location on the Wages of Black Women and White Women." Journal of Urban Economics 18 (1985): 350-363.

Straszheim, Mahlon R. "Discrimination and the Spatial Characteristics of the Urban Labor Market for Black Workers." Journal of Urban Economics 7 (1980): 119-140.

Vrooman, John and Stuart Greenfield. "Are Blacks Making It in the Suburbs? Some New Evidence on Intrametropolitan Spatial Segmentation." The Journal of Urban Economics 7 (1980): 155-167. 